\title{
Self-Abdication and Otherness in Philip Roth's The Human Stain (2000)
}

\author{
Assia Mohdeb \\ Department of English, Faculty of Arts and Languages \\ University of Bejaia,, Bejaia, Algeria \\ Sofiane Mammeri \\ Department of English, Faculty of Arts and Languages \\ University of Bejaia, Bejaia, Algeria
}

\begin{abstract}
:
Identity, in one of its understanding, signifies a set of characteristics that make up a person's ethical faithfulness to, identification with, and pride of one's origin, tradition, and culture. Remaining true to one's identity and being faithful to the core values of one's culture is a complicated matter when it comes to a black living in white society like America, where color and racial identity are rudimentary prerequisites in self-definition and naming. Philip Roth's novel entitled The Human Stain (2000) shows how some black figures undress their black identity to wear the prestigious white one to go onward with life as full selves, to have access to all the privileges the whites enjoy, and, above all, to live without the specter of race and the decisiveness of epidermal signs. The novel calls into question and revision such essentialist notions as other, class,andrace by describing the crises the subject or self undergoes in the light of racial prejudices, center-periphery relations, and class stereotypes. The present paper, then, addresses the act of self-abdication the protagonist, Silk Coleman, carries out to overstep the feeling of otherness and to dodge racial discrimination. The paper looks into the notions of selfhood and Otherness by negotiating the definition of the self and the distortion it undergoes in its encounter with the Other. The study aims at revealing, primarily, the effects of Black racial-passing, a common phenomenon in American society of the first half of the twentieth century, on familial relationships and cultural heritage. It also reveals the weight of gender and class discrimination in the individual's identity formation and well-being.
\end{abstract}

Key words: Other, racial-passing, self, self-abdication, The Human Stain

Cites as: Mohdeb, A., \& Mammeri, S. (2019). Self-Abdication and Otherness in Philip Roth's The Human Stain (2000). Arab World English Journal for Translation \& Literary Studies, 3 (1) 178-189. DOI: http://dx.doi.org/10.24093/awejtls/vol3no1.14 
AWEJ for Translation \& Literary Studies Volume, 3 Number1. February 2019

Self-Abdication and Otherness in Philip Roth's

Mohdeb \& Mammeri

\section{Introduction}

Otherness is a specter that haunts individuals, communities, whole cultures, and races. It has to do with inscribing or associating inferior qualities with specific categories of society because of race, sex, color, or class. The phenomenon manifests itself in the form of bigotry which excludes certain categories in society from standard definition and prevents them from economic and social privileges. In her article entitled " The Representation of the Indigene", Terry Goldie (1995) suggests that "since Fanon's Black Skin, White Masks (1952), it has been a commonplace to use 'Other' and 'not-self' for the white view of blacks and the resulting black view of themselves" (p. 233) and that, Goldie, carries on, "presumably the first instance in which one human perceived another as Other in racial terms came when the first recognized the second as different in color, facial features, and language' (1995, p. 235). In this understanding, Otherness is defined in relationship to the individual's imperfectability, deficiency, and lack of certain qualities and values. Besides, it touches upon his ethical bearing as well as his social standing, but more importantly, considers the individual as an object rather than a subject.

Juxtaposed with Otherness is the notion of the self or the subject. The latter is a form of identification which is defined in opposition to and conflict with the non-self. In this understanding, selfhood shows signs of perfection, wholeness, and upward mobility at the cultural and social levels, and encompasses categories of high ethnical descent and powerful gender belonging. In the philosophical discourses of enlightenment, the notion of selfhood is confined to the white European male subject. This favoritism in definition and conceptualization excludes basic defining elements of human identity including race, ethnicity, class, and sex. On this Mihaela Dumitrescu (2001), writes:

Modernism, otherwise so obsessive about subjectivity in all its forms, has failed to give a satisfactory answer to the question "what is the 'I', and what exactly makes it what it is?" Such a failure is easy to understand if we take a broader perspective and consider the ideological, social framework (modernity), not just its strictly aesthetic correlate (modernism). The very paradigm of modernity relies heavily on the idea of universal reason and of social progress achievable through advances in knowledge, as illustrated by the "grand narratives" (or "grands récits", Jean-François Lyotard's terms) of the Western world....the metanarratives of modernity have one major flaw: they aim along the lines of the Enlightenment and of Western philosophical traditions - to define a generic human nature and destiny without taking into account the individual, the particular, the local, the different, the Other.(p. 11)

\section{Discussion}

Philip Roth's third novel in The American Trilogy, The Human Stain (2000), delves into the notions of identity, Otherness, racism, and center-periphery relations. The text is filled with references to forms of essentialism - race, class, and gender - upon which a struggle for definition, naming, and equality do emerge. The present paper addresses the notion of identity by highlighting the relationship between self-making and the socially and culturally constructed identity. It reveals

Arab World English Journal for Translation \& Literary Studies 
AWEJ for Translation \& Literary Studies Volume, 3 Number1. February 2019

Self-Abdication and Otherness in Philip Roth's

Mohdeb \& Mammeri

the struggle for naming and definition for socially and racially disadvantaged groups in white American society of the first half of the twentieth century.

The Human Stain is set in America of the 1990s, but, through a series of flashbacks, the narrative regresses in time to the first half of the twentieth century, precisely to New Orange of the forties. The novel, thus, is conscious of two historical events associated with the two different periods of time it portrays; the issue of racial-passing characteristic of the forties and the political correctness typical of the nineties or what the narrator Nathan Zuckerman calls "an enormous piety binge, purity binge" (Roth,2000, p. 2) in reference to one major event of the decade; the impeachment of President Bill Clinton followinghis affair with Monika Lewinsky.

The novel tells the life as well as the death story of Silk Colman, an African-American classics professor and dean at the Athena college of New England, who passes to a white Jew to live without the specter of race and the authority of skin color. To firsthand appearances, as it comes out at the outset of the novel, Coleman is a high-status man, well-versed in the classical literature. Yet, Coleman has been "misjudged, misused, besmirched" (Roth, 2000, p. 20) and accused of racism by his colleagues at Athena because he referred to two absentees in his class, who revealed to be of African-American descent, as 'spooks'. Following this crisis which destroyed the academic career, Coleman resigns from Athena and resorts to a local novelist, Nathan Zuckerman, to weave his story. Still, melancholically distressed by the death of his wife and the loss of his prestigious academic career, Coleman enters into a romantic relationship with a custodian woman half of his age, Faunia Farley, an affair which Dephine Roux, Coleman's college at Athena, has used to unleash rumors to taunt his reputation. The novel ends with the death of Coleman and Faunia in a car accident caused by Faunia's ex-husband, Les Farley.

The Human Stain capitalizes upon the protagonist's tragic demise not only through his doomed death, his tragic fall into the doomed tartar, but through feigning a white identity that tarnished his family and his race. Coleman Silk's racial passing to a white Jew to dodge the decisiveness of racial discrimination and to live a more liberating and fulfilling life turned against his expectations and ruined his life dreams; he ends up being considered a racist white man and dies for his choice of Jewishness at the hands of an anti-Semite, Lester Farley.

The Human Stain opens with an epigraph from Sophocles' "Oedipus the King," and thus it thematically and formally imitates the traditional Greek tragedy. The epigraph reads Oedipus "words asking "what is the rite of purification and how shall it be done." (Roth, 2000, x). As an answer, Creon replies Oedipus' question saying "by banishing a man, or expiation of blood by blood." (Roth, 2000, x). The epigraphs underscores the essence of Roth's text, The Human Stain by referring to the tragic end Silk Coleman has met and the shame he has brought to his family through his racial-passing. Like Oedipus, the King in Sophocles' play, Coleman Silk, in Roth's The Human Stain, is rewarded the Hawthornian Letter of shame and disgrace as a result of his act of impersonation. Oedipus Rex believed that he had spared himself the crime of murdering his father and marrying his mother, only to find at the end that his thought has failed him. Similarly, Coleman espouses the Greek hubris to conduct a racial passing to white Jewishness, only to die at

Arab World English Journal for Translation \& Literary Studies 
the end for such a choice. Both figures, Coleman and Oedipus Rex, have tried to affect their doomed destiny in pursuit of what Elaine Safer calls "people's idealist desire for purification," (2006,p.124)and have discovered that fate is inescapable and any attempt to change or evade it results in fatality. Safer, (2006) writes:

Coleman feels that his color stains him in a society where being the other, an AfroAmerican, makes one the object of prejudice. His desire for purification- and thus for freedom- convinces him to pass as white. Just as Oedipus believes that he has escaped the destiny of marrying his mother and killing his father, so does Coleman assume that he has avoided the fate of a black man by passing as white. (p. 124).

In the philosophy of the French modernist philosopher Jean Paul Sartre, the freedom of choice is the engine that drives and directs the plotline of the individual's life. Being free, the individual can affect his destiny and overturn the reality of class, culture, and race conditions granted at birth. Yet, alongside his assertion of human freedom, Sartre gives the reverse side of that notion in what he calls facticity', the factual background upon which, many believe, freedom and choice cannot be worked out. He begins his section on "Freedom and Facticity" in Being and Nothingness (1956) with a recognizable statement on determinism, saying:

I am not "free" either to escape the lot of my class, of my nation, of my family, or even to build up my own power or my fortune or to conquer my most insignificant appetites or habits. I am born a worker, a Frenchman, an hereditary syphilitic, or a tubercular. (p. 619)

Nevertheless, Sartre argues that the notion of facticity is just an excuse taken for granted by man to justify his impotence and frailty. For him, the human being is not bound by such background factual realities as class, race, or language; rather he is endowed with freedom and choice to decide upon his destiny in life. In another context, in accordance with Sigmund Freud's notion of the unconscious recurrence of unwanted and buried experiences, the postmodernist philosopher Jacques Derrida underscores the uncertainty of the effacement of the stain and its plausible recurrence after erasure. He (2008), writes:

Granted, every human can, within the space of doxic phenomenality, have the consciousness of covering its tracks. But who could ever judge the affectivity of such a gesture? Is it necessary to recall that every erased trace, in consciousness, can leave a trace of its erasure whose symptom (individual or social, historical, political, etc.) will always be capable of ensuring its return? (pp. 135-36)

The philosopher seems to agree on the impotence and inability of the human being to exercise choice in this context. For Derrida, the ability to judge the successful effacement of a trace or stain oversteps the scope of human knowledge, erudition, and choice. Accordingly, Derrida also seems to contradict Sartre's view on free will and determination by emphasizing the interference of destiny, or the chance of changing the plotline of specific actions and events.

Arab World English Journal for Translation \& Literary Studies 
AWEJ for Translation \& Literary Studies Volume, 3 Number1. February 2019

Self-Abdication and Otherness in Philip Roth's

Mohdeb \& Mammeri

Born to an African-American origin, Coleman silk is granted right from birth, in the view of the white society's judgment, an inferior race and class and viewed, to use Toni Morrison words, as "a fabricated brew of darkness and otherness" ( 1992, p. 38). Yet, in the dream of liberating the self following the Sartrian "exhilarating notion of freedom" (Roth, 2000, p. 138) to challenge predestiny and determinism, Coleman passes to a white Jew and spends the whole of his life feigning an identity other than his; "he had served out his stint and did his time as a white" (Roth, 2000, p. 182); he also secured a white wife, white children, and a prestigious academic career at Athena college of New England community.Coleman's decision to pass to a white Jew has a long history with his family's experiences and exposure to bigotry and social exclusion while living in East Orange in the 1940's America. Nathan Zuckerman, the novel's narrator, suggests that "Even in the East Orange he had not escaped the minimally less malevolent forms of exclusion that socially separated his family and the small colored community from the rest of East Orange-everything that flowed from what his father called the country's Negrophobia" (Roth, 2000, p. 103).

Here, in Coleman's father's viewpoint, the notion of 'Negrophobia' is accounted for by the blacks' skin color and the inferiority of the black race and culture, what he calls "the presumption of intellectual inferiority. Somehow or other, if not directly by words, then by facial expressions, by tone of voice, by impatience, even by the opposite - by forbearance, by wonderful display of humaneness" (Roth, 2000, p. 103).

In his book Totality and Infinity: An Essay on Exteriority (1991), Levinas discusses the relationship between the self and the Other. Levinas argues that the self and Other do not make up a collectivity in which the I, the self, can take in the Other to it. For him "the absolutely other is the Other. He and I do not form a number. The collectivity in which I say 'you' or 'we' is not a plural of the I. Neither possession nor the unity of number nor the unity of concepts links me to the stranger. The stranger who disturbs the being at home with oneself (p. 39). The failure of the I to include, possess, and absorb the Other into its context is accounted for by "the strangeness of the other, his irreducibility to the I, to (his) thoughts and (his) possessions... a calling into question of the exercise of the same" (Levinas, 1991, p. 39).

As black Others, Coleman and members of his family cannot be embraced, considered, and accepted by the East Orange white people because, as in Levinas' understanding, they are irreducible to each other and "cannot be totalized" (1991, p. 35). Instead of promoting brotherly love, co-existence , and attempts towards reconciliation and sympathy, the East Orange academic and religious institutions have begged off any contact or rapprochement between the two races; laws decree "prejudice in academic institutions against colored students" (Roth, 2000, p. 86) and read that :

various services and Sunday schools for the colored (will) be conducted, outside basic church law, in the colored families' houses. Later, the swimming pool at the high school was shut down by the school superintendent so that the white kids wouldn't have to swim with the colored kids (Roth, 2000, p. 122).

Arab World English Journal for Translation \& Literary Studies 
AWEJ for Translation \& Literary Studies Volume, 3 Number1. February 2019

Self-Abdication and Otherness in Philip Roth's

Mohdeb \& Mammeri

Almost all members of the Coleman's family have been victims of racism and bigotry and, in the vanguard, Coleman's father, Mr. Silk. After the loss of his optical business in the depression time of the thirties, Coleman's father declines to accept the meanest job that is "in no way commensurate with his professional trainings" (Roth, 2000, p. 86) as a college graduate to meet the needs of his family; he worked as "a waiter in dining car" (Roth, 2000, p. 93) and there he "had to put up with insults and prejudicial treatment" (Roth, 20000, p. 103). Like the father, Coleman's mother, the most 'intelligent', 'knowledgeable', 'reliable', and capable' of all the Newark hospital nurses (Roth, 2000, p. 86) of the New Orange, as the Jewish Dr. Fensterman suggests, was the least to be respected, valued and to be considered for entitlement to the position of the head of nurses.

Racial oppression reaches its extended breadth and exaggerated phase with Coleman Silk. Unlike Mr. Silk, Coleman's father, who copes with Otherness through ignorance or what Coleman calls "defenselessness", Coleman could not accept to be relegated to the background of society and be judged by the color of his complexion. He even wonders how his father "has taken this shit? In one form or another taken shit like this in that dining car every single day! In that dining car every single day!" (Roth, 2000, p. 109). Coleman's experience of racial discrimination has started early in his life: as a boy studying at New Orange high school, with all the academic prowess and the dexterity he shows, being "an enthusiastic, quick-witted boy and a straight-A student" (Roth, 2000, p. 103), Dr. Fensterman suggests to Coleman to be graduated as "salutatorian" by getting B's in the finals in return for "an interest-free, nonreturnable loan of three thousand dollars" (Roth, 2000, p. 87) and thus giving his son, Bert, the opportunity to be graduated as valedictorian.Moreover, as a sailor at the Norfolk naval base in Virginia at the close of World War II, Coleman witnessed firsthand experience with bigotry when he is thrown out of the navy as "his name didn't give him away as a Jew-because it could as easily have been a Negro's name"(Roth, 2000, p. 16). Still, at Howard, the black university he attended to fulfill the dream of his father, Coleman has confirmed that again he is a "Negro" when refused to be given a hot dog at Woolworth in Washington D.C. Upon this, Coleman concludes that "in the East Orange high class valedictorian, in the segregated South just another nigger...the impact was devastating. Nigger - and it meant him" (Roth, 2000, p. 102).Still, while dating the white Icelandic girl, Steena Pallson, thinking to wed her, Coleman brings her to his parents' home for dinner, believing that love outdoes racial prejudice and stereotypes. Yet, on their way back home from the East Orange to New York, Steena tells Coleman that she "can't d o it..she raced alone from the train as though from an attacker and did not phone him or even try to see him ever" (Roth, 2000, p. 125).

Disappointed by Steena's behavior and tormented by the life of segregation he has experienced wherever he goes; in the East Orange neighborhood, the East Orange high school, Washington D. C, at the navy and even at Howard, Coleman makes it up to choose "the future into his own hands rather than leave it to an unenlightened society to determine his fate-a society in which more than eighty years after emancipation proclamation, bigots happened to play to large a play to suit him" (Roth, 2000, p. 120).Coleman undresses his black identity to spare himself the feelings of Otherness and the process of objectification from the white subjects. Critical race theorist Cheryl Harris suggests that:

Arab World English Journal for Translation \& Literary Studies 
AWEJ for Translation \& Literary Studies Volume, 3 Number1. February 2019

Self-Abdication and Otherness in Philip Roth's

Mohdeb \& Mammeri

Becoming white meant gaining access to a whole set of public and private privileges that materially and permanently guaranteed basic subsistence needs and, therefore, survival. Becoming white increased the possibility of controlling critical aspects of one's life rather than being the object of others' domination. (1996, p. 277)

In his battle for emancipation proclamation, the black historical narrative to attain equality with the whites and his ownnarrative to shirk the authoritative voice of the 'weness, Coleman didn't spare a means to reach his aim. In the first occasion, as a boxer, Coleman feigns a white Jewish identity to get a "four year scholarship to Pitt" (Roth, 2000, p. 98) by telling the Pitt Coach that he is white, he is "neither one thing nor the other. He is Silky Silk. That's enough" (Roth, 2000, p. 98). Then, in another occasion, Coleman fights an African-American man and was not ashamed to call him nigger. More important than all these, against his parents' wish to marry a light-skinned girl of a prestigious black family, Coleman weds the white Iris Gittelman to carry out his "first large payment,"(Roth, 2000, p. 136) in invigorating his plan. Nevertheless, Coleman's racial passing is not only a decision to undermine Otherness and the feelings of inferiority associated with his race, rather he aspires towards what Toni Morrison calls "the human freedom - the thing coveted most of all" (1992, p. 37), and what himself calls "freedom of the raw I," a liberating power that refuses to assimilate and respond to the dictates of the 'We' and the 'they' categories. He (2000) suggests:

With both bulwarks gone - the big brother overseas and the father dead - he is repowered and free to be whatever he wants, free to pursue the hugest aim, the confidence right in his bones to be his particular I. free on a scale unimaginable to his father. As free as his father had been unfree. Free now not only of his father but of all that his father had ever had to endure. The impositions, the humiliations. The obstructions. The wound and the pain and the posturing and the shame - all the inward agonies of failure and defeat. Free instead on the big stage. Free to go ahead and be stupendous. Free to enact the boundless, self-defining drama of the pronouns we, they, I. (p. 109)

Here, in the above quotation, Coleman highlights the coming of I on the stage to play its history and authority against the voices of the other, and praises the promising prospects the subject, the I, would access and realize. The struggle between the me and the us, in Coleman's conceptualization, is the struggle between self-assertion and the socially constructed identity or self. He seems to support the myth of self making which eulogizes individual potentialities to craft his lot. He resembles Fitzgerald's the great Gatsby and Emily Bronte's Heathclif who has raised himself from dust and carried their own entitlement to prestigious social belonging and identities. He carries on saying:

You can't let the big they impose its bigotry on you any more than youan let the little they become a we and impose its ethics on you. Not the tyranny of the us and its us-talk and everything that the wewants to pile on your head. Never for him the tyranny of the we that is dying to suck you in, the coercive, inclusive, historical, inescapable moral we with its insidious E Pluribus unum. Neither the they of Woolworth nor the we of Howard instead

Arab World English Journal for Translation \& Literary Studies 
AWEJ for Translation \& Literary Studies Volume, 3 Number1. February 2019

Self-Abdication and Otherness in Philip Roth's

Mohdeb \& Mammeri

the raw I with its agility. Self-discovery. Singularity. The passionate struggle for singularity. (Roth, 2000, p. 108)

Still, for Coleman, the struggle between the "I" and the "we" and his journey towards freedom and enlightenment, as it is apparent in other instances in the novel, entails liberating his imprisoned Eros against the preconceived logistics of tradition, righteousness, and authenticity. Coleman seems to back up the cathartic exaltation of emotions over the bog of rationalism, morality and a search for meaning and significance. He suggests:

The obligation to subject my life to hers and its vagaries. Its vagrancy, its truancy. Its strangeness. The delectationof this elemental Eros. Take the hammer of Faunia to everything outlived, all the exalted justifications, and smash your way to freedom. Freedom from the stupid glory of being right. From the ridiculous quest for significance. From the never ending campaign for legitimacy. The onslaught of freedom at seventy one, the freedom to leave a lifetime behind-known also as the aschenbachian madness. (Roth, 2000, p. 171)

Following the racial passing act, Coleman effaces the difficulties that bump up his intellectual progress and he exalts his notion of freedom and self-assertion. It is also met with grievous consequences. His mother's warning words reading that "all his attempts to escape will lead him back to where he begun" (Roth, 2000, p. 140) have come true as late in his life, Coleman was accused of racism at Athena. Viewing him as a rascal threat to the ideals of freedom, democracy, and equality following his use of a racial epithet to describes two African-American students in his class, the intellectuals at Athena force him out of the academe to purify the white race from his racist thoughts. Still, Coleman's act of self-invention and cultural effacement have resulted in the tearing up of the notion of the family, the dissolution of relational ties and the loss of the cultural heritage as a reference to belonging, naming and identification for posterity. Coleman did not only kill his mother, preventing her from her grandsons but also killed his sons by his concealment stories about their grandparents and cousins beings German Jews with whom he lost contact ever. His children could not understand their father self-invention story about their ancestors which leave them unconfident, unsure of their present and their past.

The class is another basic element in the constitution of human identity and the continuous struggle between self and Other. Class, like race, divides society into what Paul Virilio calls the "haves, and the have-not" (1997, p. 74) and set about discomforts and contradictions in terms of social advantages, social ease and mobility. Class manifests itself through forms of deprivation, dispossession and even oppression which is worked out on certain categories of the social order. In the World of The Human Stain, Faunia Farley, Coleman's Viagra, represents the dispossessed category, 'the wretched of the Earth', in Fanon's words. Faunia works as a custodian at the Athena College and labors in one of the prairies as a part-time farmer to pay the fees of her rent. Faunia experienced a traumatic childhood, being rejected by her mother and continuously humiliated, victimized and beaten by her stepfather. In his description of Faunia, Coleman tells Nathan Zuckerman that she "has been exiled from the entitlement that should have hers. Declassed...a

Arab World English Journal for Translation \& Literary Studies 
AWEJ for Translation \& Literary Studies Volume, 3 Number1. February 2019

Self-Abdication and Otherness in Philip Roth's

Mohdeb \& Mammeri

stepfather undid her, upper bourgeois undid her" (Roth, 2000, p. 28). Escaping the oppression of her family, Faunia first left home and then married an ex-Vietnam vet in the hopes to change her destiny, but "all that they had together was trouble" (Roth, 2000, p. 29) and ended in separation and her two children have been " asphyxiated in the heater fire" (Roth, 2000, p. 53). In its reference to the different social classes to which the two lovers Colman Silk, Ex-dean at Athena College, and Faunia Farley, a custodian at the college door, belong, the text involves, apart from racial passing, class passing. Roger Ebert writes that The Human Stain "involves two different kinds of passing: Crossing the race line, and the class line. Coleman and Faunia must deal with each other despite their lack of common references, education, background, assumptions, manners of speech, tastes and instinct" (2006, p. 305).

Sex is another form of Otherness in The Human Stain. It manifests itself through the kind of "social castration", to use Sandra Gilbert's and Susan Gubar's word, that certain women experience under the marriage institution, through love affairs and as single women exploited by married males. Barbara and Castellano Turner (1994)affirm that men and women are seen as different "in personality traits, in physical characteristics, in interests, in occupational roles and status levels, and in many other ways" (p. 95). In this view then, women are not innately inferior but society, as Simone De Beauvoir suggests, amounts to their inferiority. She writes:

One is not born a woman but rather becomes a woman. No biological, or economical fate determines the figure that the human female presents in society; it is civilization as a whole that produces this creature...only the intervention of someone else can establish an individual as an other...the child would hardly think of himself as sexually differentiate. (1994, p. 267)

We have referred above to class as one of the ordeals in Faunia's miserable life. Yet, Faunia is also a victim of patriarchy. Because of her miserable situation, men, Coleman suggests, "have beaten a shit out of her" (Roth, 2000, p. 171); all what Les Farley did "was to make her his punching bag" and all that the other men did "was to make her whore or one among them" (Roth, 2000, p. 161). In marriage, Faunia was not well off. Lester Farley, she tells Coleman, "regularly beat her up. Beat her black and blue" (Roth, 2000, p. 29). Still, working as waitress in Florida, retired businessmen asked her for" a few nights a week" in return for " nice apartment, nice cloth and a nice new Pinto and charge accounts at all the Bal Harbor clothing shops and at the jewelry store" (Roth, 2000, p. 160).

Professor Delphi Roux, Coleman colleague at Athena, is another oppressed female figure in the novel. Delphine Roux, according to Nathan Zuckerman, has been graduated from 'Ecole Normale Supérieure de Fontenay' and has "read the entire body of French literature" philosophy, English language and literary history (Roth, 2000, p. 188). Delphine's feminist burden, in the text, is to free herself and her female colleagues and students from the sexist oppression of Coleman Silk. Identifying him with her ex-classicist professor with whom she had an "impassioned affair" (Roth, 2000, p. 186), but who turned to be "playing seduction against her" (Roth, 2000, p. 187), Delphine considers Coleman as a menace to her and other female lives. Her trouble with Prof. Silk started

Arab World English Journal for Translation \& Literary Studies 
AWEJ for Translation \& Literary Studies Volume, 3 Number1. February 2019

Self-Abdication and Otherness in Philip Roth's

Mohdeb \& Mammeri

when an attendee of Prof. Silk's Classical tragedy courses, Elina Mitnick, complains to Prof. Roux that Mr. Silk's choice for Euripîdes' Hippolytus and Alcestis are "degrading to women" (Roth, 2000, p. 184), and calling Mr. Silk to her Office to see into the matter proved to be a failure as he disregards their feminist perspectives, both of them. The issue is worsened when another student of Prof. Silk, Tracy Cummings, hurries to Pro. Roux "close to tears, barely able to speak, baffled at having learned that, behind her back, Professor Silk had employed a malicious racial epithet to characterize her to her classmates" (Roth, 2000, p. 193). Prof. Roux has forwarded the affair to the new dean of the faculty because she knows that calling Prof. Silk to her office to discuss the matter will be useless, simply because any other "upstart female daring to inquire into his conduct, yet another woman whose concerns he must trivialize should he deign even to address them" (Roth, 2000, p. 193). After Coleman's resignation from the Athena College, Prof. Roux discovers Mr. Silk's love affair with the poor, Faunia Farley, and confirms her doubts about Coleman's misogynist intentions. As Zuckerman suggests:

When she read of the illiteracy that limited Faunia to performing only the most menial of janitorial tasks, she understood that Coleman Silk had managed to unearth no less than a misogynist's heart desire: in Faunia Farley he had found someone more defenseless even than Elena and Tracy, the perfect woman to crush. For whoever at Athena had ever dared to affront his preposterous sense of prerogative, Faunia Farley would now be made to answer. (Roth, 2000, p. 194)

Still, thinking over the affair between Coleman and Faunia, Delphine ends up reading Coleman's behavior not only as a kind of playing, but also a form of revenge on her. For her, Coleman takes Faunia as a playing toy to exercise his revenge upon her, suggesting " seething at the thought of the viciousness that could make of this dreadfully disadvantaged woman who had already lost everything a toy, that could capriciously turn a suffering human being like Faunia Farley into a playing only so to revenge himself on her"( Roth, 2000, p. 195). Greatly intimidated and vexed by Coleman's deed, which she reads as defamation and an encroachment upon women, Faunia Farley and her, Prof. Delphine writes an anonymous, unsigned letter to Mr. Silk which threatens to denounce him publically and which reads:

Everybody knows you are

Sexually exploiting an abused,

Illiterate woman half your age. (Roth, 2000, p. 38)

Surely Roth's inclusion and description of Delphine Roux and Faunia Farley is paramount and line up with the text's broader theme of otherness, which extends to the female figures in the novel. Roth painstakingly meticulous focus on Delphine Roux, her status at Athena and her role in the academe is significant in the context of the political purity characteristic of the American Academy of the 1990s. .Even though her name is inspired from the Greek priestess of Delphi, Delphine Roux represents all that the priestess of Delphi is not and her academic community at Athena is far removed from Plato's academe at Athena in Greece. Delphine's active role in condemning Coleman as racist following his use of a racial slur confirms the political righteousness or

Arab World English Journal for Translation \& Literary Studies 
AWEJ for Translation \& Literary Studies Volume, 3 Number1. February 2019

Self-Abdication and Otherness in Philip Roth's

Mohdeb \& Mammeri

purification typical of the American academe in the nineties and which lead to the impeachment of the president ,Bell Clinton in the Congress. The issue of purification, of ridding society from racism and imperfection, in Roth's understanding, is symbolic as any attempt to work it out results in failure. Roth wants to suggest, as Faunia confesses at the close of the novel, that "we leave a stain, we leave a trail, and we leave our imprint. Impurity, cruelty, abuse, error, excrement, semen" (Roth, 2000, p. 242). He rejects human perfectibility and utopian thinking and behavior: He is seemingly reconciled to the inevitability stained creatures that we are. Indeed, Roth's enemies "are utopian perfectionists in the disguise of rapid anti-communists, frenzied cultural radicals, selfrighteous feminists, puritanical politicians and guardians of political correctness" (Levine \&Papasotiriou, 2005, p. 234).

\section{Conclusion}

The Human Stain takes into consideration the issue of identity and comments on such essentialist concepts as self, other, race, sex, and class. The text as a whole is reading in the way notions of race, class, and otherness contribute in the formation and the disturbance of the human identity. While, at some points, the text confirms some individuals' acceptance, identification, and harmony with the race, the class, and the gender to which they affiliate, at others, it shows instances and attempts at dodging and transcending these essentialist notions which become hinders to their progress in life. Considering racial passing, the narrative exposes the advantages and the disadvantages associated with the phenomenon. By passing to a white Jew, the protagonist of the novel, Coleman Silk, closes the door to his past and identity, separates from what he is handed at birth, and challenges the authority of the "they and "we", to usher, in return, into the realm of the I and self-dominance. Coleman's racial passing to a white subject has provided him a future crowned with a prestigious academic career at the Athena College, middle class social life, and a white family. Yet, his choice is also met with and paid back by an accusation of racism and bigotry. Roth wants to suggest that the human stain, which in the text directs at the individual's rejection and abnegation of one's identity and past, is never effaced; its recurrence and re-emergence to remind you of it, to torment you and, may be, to teach you, is always plausible.

Still, through class and sexism, Philip Roth shows the difficulties and the troubles the socially disadvantaged groups face daily in their battle for definition and survival. Again, as is the case with race, class and sexism are forms of Otherness, upon which the aforementioned categoriesare excluded from standard definition and entitlement to social mobility and equality. The text is laced with the social ills such as the misery, the deprivation, and the dispossession poor people endure daily and it makes references to the subjugation and oppression of the female figures under marriage and through love-relationships.

\section{About the Authors}

Assia Mohdeb is Assistant Professor of Literature in the Department of English at Bejaia University, Algeria. Her research interests include Anglo-American Literatures, African Literature, Literary Stylistics, and Literary Criticism. She teaches several graduate \& postgraduate courses such as Anglo-Saxon Literature, Culture \& Civilization, and Literary Theory. She is supervising M.A. Theses in Literature \& Civilization. Also, she has presented many papers in

Arab World English Journal for Translation \& Literary Studies 
AWEJ for Translation \& Literary Studies Volume, 3 Number1. February 2019

Self-Abdication and Otherness in Philip Roth's

Mohdeb \& Mammeri

national and international conferences and workshops. Similarly, she published some papers in national and international scientific journals. Currently, Assia is working on a Ph.D. in Postmodern Literature. https://orcid.org/0000-0001-7935-9961

Sofiane Mammeri is Assistant Professor of Sociolinguistics in the Department of English at the University of Bejaia, Algeria. His research interests include Sociolinguistics, Theoretical Linguistics, Discourse Analysis, Supra-segmental Phonology, and Translation Studies. He teaches several graduate \& post graduate courses such as Phonetics \& Phonology, Sociolinguistics, and Discourse Analysis. He is supervising M.A. Theses in Applied Linguistics. Also, he has presented many papers in national and international conferences and workshops. Similarly, he published some papers in national and international scientific journals. Currently, Sofiane is working on a Ph.D. in Sociolinguistics. https://orcid.org/0000-0002-0444-2725

\section{References}

De Beauvoir, S. (1974). The Second Sex. Trans. H. M. Parshley. New York: Vantage Books.

Derrida, J. (2008). The Animal that therefore I am. Trans .David Willis.New York: Fordham University Press.

Dumitrescu, M.(2001). "Modernism, Postmodernism, and the Question of Identity." Dialogos.3. Ebert, R. (2006). Movie Yearbook 2006. Kansas City: Andrew McMeel pub.

Harris, C. (1996). "Whiteness as Property." In Crenshaw Kimberlé, Neil Gotanda and Garry Peller, (Eds). Critical Race Theory: The Key Writings that Formed the Movement. New York: New York Press.

Goldie, T. (1995).“The Representation of the Indigene.” In Bill Ascroft, Gareth Griffiths \& Helen Tiffin ,(Eds). The Postcolonial Studies Reader. NewYork: Routedge.

Levinas, E. (1991). Totality and Infinity: An Essay on Exteriority. Trans. Alphonso Lingis. Boston: Kluwer Academic Publishing.

Levine,P.\& Papasotirio, H.(2005). America since 1945: The American Moment. New York: Palgrave Mcmillan.

Morrison, T. (1992). Playing in the Dark: Whiteness and the Literary Imagination. Cambridge:Harvard University Press.

Roth, P. (2000). The Human Stain. London: Vantage.

Safer, E. B. (2006). Mocking the Age: The Later Novels of Philip Roth. Albany: SUNY Press.

Sartre,J.(1956). Being and Nothingness. New York: Washington Square Press.

Turner, B. \&Castellano, T. (1994). "Social Cognition and Gender Stereotypes for Women Varying in Age and Race. In Barbara Turner and Lillian Troll, (Eds). "Women Growing Older: PsychologicalPerspective. sMichigan: Sage.

Virilio, P. (1997). Open Sky.Trans. Julie Rose. London: Vantage.

Arab World English Journal for Translation \& Literary Studies 